\title{
5
}

\section{International Organizations in Education: New Takes on Old Paradigms}

\section{Dennis Niemann}

\section{Introduction ${ }^{1}$}

The diffusion of education policies is a central topic in this volume. As outlined in the introduction by Windzio and Martens (Chap. 1), not only do states tend to orient their education systems toward global models, accepted standards, and best practices but also the international community emulates overall trends. Transnational and international actors play an increasingly important role in shaping global models of education. The way in which education is ideologically framed on the

\footnotetext{
${ }^{1}$ This chapter is a product of the research conducted in the Collaborative Research Center "Global Dynamics of Social Policy" at the University of Bremen. The center is funded by the Deutsche Forschungsgemeinschaft (DFG, German Research Foundation)_project number 374666841SFB 1342.

D. Niemann $(\bowtie)$

Institute for Intercultural and International Studies (InIIS) and Collaborative Research Centre 1342 "Global Dynamics of Social Policy”, University of Bremen, Bremen, Germany e-mail:dniemann@uni-bremen.de
} 
international level could have important consequences for domestic education systems, since national education reforms are heavily influenced by international developments and policy recommendations stemming from international actors (see Martens et al. 2010). Within a world society, no state is an isolated island (Meyer et al. 1997). As part of a globalized educational subsystem, states are encouraged to respond to initiatives from the international level and act in accordance with the accepted or appropriate behavior. This also means that internationally defined and disseminated standards provide templates for organizing domestic education reforms.

Certain international organizations (IOs)—understood and used interchangeably with the term "intergovernmental organizations" (IGOs) - became central players in the global discourse on education (Niemann and Martens 2021). IOs, therefore, exceed the role of mere instruments for powerful states to use in the pursuit of their national interests and are more than just state-controlled arenas for multilateral coordination and cooperation. IOs are depicted as independent policy entrepreneurs and their agency in education policy stems from their status as legitimate, impartial, and expert entities (Martens and Niemann 2013). This actor-like status also exhibits IOs' own possible interests and preferences regarding policies, which neither necessarily reflect the interests and preferences of their member states nor do they reflect the IO's original mandate. IOs are able to make their own decisions regardless of the wishes and virtues of their members. Generally, IOs can be considered autonomous actors if their actions and influence are not fully controlled by their member countries (Hasenclever and Mayer 2007). Understanding IOs as complex bureaucracies provides additional explanations as to why they could develop a life of their own and become policy entrepreneurs (Barnett and Finnemore 2004). This role of IOs makes them vital actors in shaping global education policies and grants them leverage in defining what constitutes proper education policy measures.

In sum, IOs can be independent actors in the field of education and can hold their own ideas about which policy goals should be pursued. With this idea-driven agency in mind, it can be assumed that IOs will be interested in disseminating their policies and influence the behavior of 
others (be it of states, substate departments, individuals, or other international institutions). This is closely linked to a soft governance approach whereby IOs refer to their moral authority and legitimacy. In addition, ideas are not universally accepted and different interpretations regarding a certain topic may compete with one another. Ideas regarding education can be rooted in different traditions, historical configurations, economic paradigms, or cultural spheres (see Chap. 1). For instance, one traditional idea regarding the purpose of education in Western Europe was that national identity could be fostered by teaching a common national history, which was then contrasted with those of other European neighbor states.

Ideas are also embedded in IOs. In establishing a set of ideas that constitute a leitmotif in terms of certain policies, complex organizational entities like IOs are influenced by different endogenous and exogenous factors. These factors include member state composition, staff, global developments, disruptive external shocks, and the like. Since the population of IOs is by no means homogeneous and given that IOs do not share the same institutional background, they are also not expected to hold the same ideas about education. Considering that there are several IOs active in the field of education-Niemann and Martens (2021) identified thirty education IOs as of 2018 - and given that there is more than one idea as to what constitutes the most effective and appropriate education policy, it is inevitable that these IOs also have various and (sometimes) competing ideas. Consequently, they may compete with one another for influence, legitimacy, and ultimately for political success.

In this chapter, I trace the leitmotifs as defined in the introduction to this volume of four globally operating education IOs over time and demonstrate how they interpret the purpose of education. I argue that during the first phase, which lasted until the late 1990s, the international education landscape was characterized by competition between major IOs embracing antipodal leitmotifs regarding the purpose of education. However, in a more recent phase, we can witness more of a cooperative, comprehensive approach; IOs involved in the field of education have started to take a more integrative, ideational approach whereby cooperation on educational projects or joint positions has intensified. Looking at the Millennium Development Goals (MDGs) and Sustainable 
Development Goals (SDGs), we can see that these meta-developments were central drivers of ideational integration. Both global roadmaps for development emphasized the importance of a holistic view on development processes. In addition, with increased focus on evidence-based policies and empirically driven assessments of education, the different IOs pursued an integrative approach toward education policy in terms of ideational framing, whereby fundamental worldviews became less important in framing the purpose of education.

This chapter is organized as follows: First, I elaborate on the importance of ideas in education and highlight the different leitmotifs regarding the purpose of education as outlined in the introduction to this volume, that is, a utilitarian economic interpretation versus a humanistic citizenship view of education (Chap. 1); I also discuss how this affects globally operating IOs. Secondly, I analyze how four globally active education IOs - the World Bank, the Organisation for Economic Co-operation and Development (OECD), the United Nations Educational, Scientific and Cultural Organization (UNESCO), and the International Labour Organization (ILO)—ideationally frame education purposes over time and demonstrate how this was linked to programmatic actions. Here, I also describe how the IOs competed at certain times and why some IOs were perceived as more dominant in the realm of international education policy. By elaborating on the pattern of cooperation and contestation between IOs, I finally conclude that nowadays they tend to cooperate and coordinate. Also, the IOs apply a more integrative and ideational approach by incorporating both utilitarian and humanistic leitmotifs.

\section{The Development of Education Ideas Within IOs}

A necessary condition for IOs to become influential (soft) governance actors includes their ability to formulate and disseminate their own education policies. In order to do so, they need to have defined concepts of desired policy outcomes and specify what the purpose of education 
should be. Whether something is seen as desirable is heavily influenced by ideas. And the proliferation of ideas could contribute to changes (or stability) in policy-making. Ideas shape policy institutions and, in turn, ideas are also shaped by them.

Since almost all IOs must rely on their capacity as policy advisors and opinion leaders, one key element of IO influence is the role and dissemination of ideas. Following Béland and Cox's definition, ideas are perceived as causal beliefs that "provide guides for action [and help] to think about ways to address problems [and] posit causal relations that guide people's decisions and preferences" (Béland and Cox 2011, 4). Ideas are modifiers that shape policy discourse and can influence policy outcomes. This renders ideas as cognitive frameworks for interpreting causal relationships between problems and appropriate solution strategies (Goldstein and Keohane 1993). How agents act in the world is strongly determined by how they perceive their environment through ideational prisms. Furthermore, the perceptions of the actors' environments are neither stable nor fixed, as the interests of actors can only be seen as given or fixed in a world where information about cause and effect is perfectly accessible. If information is imperfect, the choices of action or behavior are always speculative to some degree. By acknowledging that information is always imperfect, actors make decisions based on uncertainty. Here, ideas come into play since ideas shape actors' preferences (Blyth 2003, 697).

Ideas are particularly important governance instruments for IOs. Their power stems from their capacity to define and interpret the issues at stake. IOs shape how the social world is constituted, and they also set the agenda for acting in this environment (Barnett and Finnemore 2004). Basically, IOs acquire ideas when they institutionalize and cultivate them within their organizational environment, but they also disseminate ideas, doing so through diverse channels such as reports, recommendations, declarations, symposia, and so forth. In consequence, an IO aligns its programmatic activities according to its (set of) ideas.

Taken together, the perception of the purpose of education is central in assessing IOs' education ideas. In short, a polarity of ideas with regard to the purpose of education can be identified between two general leitmotifs (see Niemann and Martens 2021). As outlined in the introduction to this volume, the goal of education can first be framed from a utilitarian 
perspective, which emphasizes the positive economic effects of investment in education. In this regard, education substantially contributes to the formation of human capital. Secondly, education ideas can also be approached from a humanistic citizenship leitmotif, which is rooted in a social liberal tradition. From this perspective, education is essential to modern societies as it establishes or maintains the political and social integration of a society (Nagel et al. 2010). Because both leitmotifs are at opposite poles of a continuum, they resemble ideal types. In addition, they are complementary rather than mutually exclusive. Subsequently, actors like IOs blend both perspectives into one ideational framework; however, one leitmotif usually dominates and is prioritized over the other. Nagel et al. (2010) have also demonstrated that both interpretations can either be applied to the individual or the collective level.

IOs' fundamental ideas regarding education are assumed to be reflected in what they publish: position papers, policy recommendations, declarations, detailed policy analyses, and the like. Hence, in this study the utterance of ideas is conceptualized as causal statements of IOs in a discourse on the purpose of education. By analyzing publications of the World Bank, the OECD, UNESCO, and the ILO from different time periods with regard to the education ideas as outlined in the introduction to this volume, I assessed how these four global IOs framed the purpose of education over time. IO documents were analyzed and coded according to the education ideas that were put forward. The selection only included documents that resemble major policy outputs of the IO, like mission statements, overall programmatic outlines, and principal policy guidelines in education. Information in the text was categorized according to predefined sets of codes derived from theory (Mayring 2003). This means that statements in documents were interpreted pursuant to theoretical categories of the relevant research variables, that is, education ideas. In addition, expert interviews with representatives of IOs were conducted to identify the predominant education leitmotif that supplements the findings in the documents. In using this triangulation approach, the weaknesses of document analysis are alleviated by the additional information collected through expert interviews and vice versa.

According to the differentiation of leitmotifs, we expect IOs with a primarily economic purpose to promote a human capital approach in 
education with a focus on the economic utility of education for personal development as well as national growth, whereas IOs with a general rights approach emphasize the humanistic values of education for both the individual as well as the collective level.

\section{Analyzing the Evolution of IOs' Education Ideas}

In this chapter, the global discourse on education purposes is analyzed. Hence, only IOs that operate worldwide were selected to have their ideational take on education analyzed. Unlike regional IOs, whose education programs are strongly influenced by the characteristics and idiosyncrasies of the respective region (see Chap. 7), it is expected that globally operating IOs also claim global validity for their program and ideas. Hence, distinctive "cultural spheres" (Chap. 1) are not a decisive factor for analyzing the education ideas of global IOs.

Of the population of thirty education IOs, six IOs operate on the global level: UNESCO, the ILO, the United Nations Children's Fund (UNICEF), the World Bank, the OECD, ${ }^{2}$ and the United Nations High Commissioner for Refugees (UNHCR) (Niemann and Martens 2021). With the exception of the OECD, all IOs are part of the United Nations system, for example, as specialized agencies. The six global education IOs can be distinguished according to their basic mandates and other such characteristics that are assumed to have consequences on the conceptualization of education ideas and how education policies are framed. While the three UN-IOs and the ILO focus on specific policy areas (education, refugees, children, and labor rights), the World Bank and the OECD focus on economic policy. Compared to other types of IOs that initially did not deal with education, economic IOs were latecomers but constantly expanded their activities in the field of education

\footnotetext{
${ }^{2}$ Clearly, the OECD is an IO with restricted membership (economically developed democracies) and hence the classification of the OECD as a "global" IO can be challenged. However, in education, the OECD's scope and influence in terms of its education activities extends well beyond its member states. The IO provides services for any state that is interested in joining the OECD's education program (Niemann and Martens 2021).
} 
(Niemann et al. 2021, forthcoming). From the sample of analyzed IOs, the general trend of economic IOs becoming involved with education topics is reflected in the World Bank and the OECD. In this chapter, UNESCO, the ILO, the World Bank, and the OECD are analyzed with regard to their ideational framing of the purpose of education.

The development of the education ideas of the four IOs is described against their historical background. It is shown that IOs' idea portfolios are not static, rather they are dynamic and influenced by both endogenous and exogenous factors. However, the core of each IO's view on education purpose remains stable over time. It can be observed that while the nucleus of education leitmotifs remained constant over time, other ideational layers were added to the portfolio. Today, all four IOs feature a relatively holistic set of education ideas.

\section{The World Bank: Development Assistance from the 'Knowledge Bank'}

Over time, the World Bank ${ }^{3}$ has become heavily invested in education, even developing its own programs to promote its vision for appropriate education policies. In short, as an independent specialized agency of the $\mathrm{UN}$, the Bank transformed from a development aid agency to an active policy advisor that produces and disseminates knowledge; it also demonstrates best practice examples in the field of education. This takes place against the ideational background of viewing education as a means to fight poverty and boost human capital, productivity, and capacities for self-development. While the Bank's concrete foci of development policies in education varied over time, the principal mission of the Bank remained constant: to provide development aid in order to reduce poverty and foster human development. Like any other organization, the World Bank and its education program is also shaped by intra-organizational frictions

\footnotetext{
${ }^{3}$ The World Bank Group consists of five sub-organizations (International Bank for Reconstruction and Development (IBRD), International Finance Corporation (IFC), International Development Association (IDA), Multilateral Investment Guarantee Agency (MIGA), International Centre for Settlement of Investment Disputes (ICSID)). "World Bank" refers to the IBRD and IDA. In education, the IBRD and IDA are the most relevant institutions, but the IFC is also incorporated, especially when it comes to involving the private sector in education funding operations.
} 
and diverging preferences among different subdepartments (Fontdevila and Verger 2020). However, the Bank's main publications outlined a coherent discursive approach in education, and its education leitmotif can be characterized alongside the cornerstones that revolve around a utilitarian understanding of education. This understanding of education developed against the historical background of the Bank, where it was both weakened and reinforced at different stages.

In a first phase spanning from the IO's inception to the late 1960s, the Bank conceptualized education as something strictly functional for development and poverty reduction. It exclusively focused on vocational training and did not view general (nonvocational) education as an important instrument for achieving its aims in development assistance. In October 1963, the first series of operational directives for the Bank's education approach were launched, which aimed at investing in creating manpower and filling the gap of missing technicians and engineers to operate modern machinery (Heyneman 2003). In fact, the Bank's very first education loan was in 1963 to Tunisia for a program in vocational training (World Bank 1999, 23). The economic-leaning idea had already become institutionalized at the early stage of its education program. By addressing the engineering problem, the generation of human capital was prioritized. However, the ideational framing of the World Bank regarding education in the 1960s rested on the assumption that education does not directly contribute to a state's overall development nor to poverty reduction; instead, it was seen as a necessary condition for facilitating the on-site operation of direct development aid projects.

The Bank's education concepts and activities were substantially broadened at the end of the 1960s under the presidency of Robert McNamara (in office 1968-1981). By acknowledging education and other social policies as contributing to the economic development of states, the Bank also altered its lending strategy and operational activities by improving the productive capacities of the poor (Mundy and Verger 2015). The new framing of education in this phase established the Bank's fundamental idea that improvements in education directly translate into economic well-being and overall societal improvements. In the 1970s and 1980s, the idea of enabling countries to help themselves became prevalent. The focus of the Bank's education program was moved to early childhood 
education and basic education because these were the areas believed to be particularly relevant for laying the foundations for sustainable economic development (Zapp 2017). Accordingly, the organizational infrastructure within the World Bank was established to fund education projects beyond vocational education, where education research was upgraded (Heyneman and Lee 2016, 9).

By the early 1980s, the predominantly neoliberal architecture was also implemented in the Bank's education program and shaped how the purpose of education was framed. By almost exclusively focusing on the development of human capital for enabling economic growth, other views on education were sidelined in this period. The Washington Consensus was of particular importance in framing the Bank's education policy agenda of utilitarianism: a reduction in public sector spending, the liberalization of markets and privatization of public enterprises, and a focus on the "rates of return" of education (Mundy and Verger 2015). From the mid-1980s, a shift toward lending for elementary-level education projects took place within the Bank's strategy, though still from a perspective of investment (Mundy 2010, 339).

The legitimacy of the World Bank and its work in education came under pressure in the late 1980 s to mid-1990s due to the identification of undesired outcomes resulting from the implementation of neoliberal policies (Bonal and Tarabini-Castellani 2009). The neoliberal paradigm was shaken and challenged. Despite this, the Bank's education ideas were still in line with neoclassical economic thinking when a Post-Washington Consensus began to emerge in the 1990s (Mundy and Verger 2015, 13), though a broader understanding of development had emerged within the Bank so that deficiencies in education, health, and other areas were acknowledged (Vetterlein 2012, 40). The Bank also began to cooperate with UNESCO and UNICEF, which ultimately led to the 1990 Education for All Conference.

Under the presidency of James D. Wolfensohn (1995-2005), the World Bank was redesigned as the "Knowledge Bank". An evidencebased focus on policies was established whereby the Bank aimed at providing advice to governments based on empirical findings. Accordingly, the Bank restructured its internal management and operational portfolio; in addition, it heavily invested in research, particularly in the field of 
education, and became a major generator of empirical data and analyses (Zapp 2017). The IO sought to become a neutral policy advisor so that it could guide decision-making in education through knowledge production and identification of best practices. Still, utility considerations and the economic development perspective were paramount in education since the economic perspective on education outcomes was dominant in analyzing education policies (see World Bank 1999). The reorientation of the Bank also created new opportunities for joint efforts with other IOs. For instance, the "Knowledge Turn" was followed by the Global Knowledge Conference in 1997, where the Bank brought together participants from all over the world and linked them all to global communication (Zapp 2017, 4).

This knowledge-centered approach of the World Bank was strengthened in the mid-2000s when emphasis was placed on the systematic research of education performance. In addition, the World Bank linked various educational studies, which included national, regional, and international research. The dialogue with recipient states intensified and the Bank introduced a holistic systematic approach; the IO took a closer look at the peculiarities of individual developing countries or regions and increasingly allowed for different approaches in developing education policies. Accordingly, the World Bank currently depicts itself as the "Solution Bank".

For the World Bank, education became central to the development agenda. The principal aim of the Bank in education has been to "help developing countries reform and expand their educational systems in such a way that the latter may contribute more fully to economic development" (World Bank 1974, i). Although the Bank currently emphasizes education as a human right (World Bank 1999, Interviews World Bank A, C 2018) and recognizes the limits of the market model for education (Robertson 2012, 198), the purpose of education in the Bank's discourse asserts an economistic leitmotif, which brings the utility of education to the fore. The World Bank's Education Strategy 2020 of 2011 emphasizes education as a basic human right but the strategy still falls under an economic paradigm in that it promotes the global standardization of curricula, private-public education partnerships for designing and conducting education projects, and the decentralization of national education 
systems (Enns 2015). In the view of the Bank, education affects how well individuals, communities, and nations fare. Countries need more highly educated and skilled populations. Moreover, individuals need more skills to become more productive, to be able to compete, and to thrive (World Bank 1999, 5). The level of acquired "skills in a workforce [...] predicts economic growth rates of a states" (World Bank 2011,3) and learning is essential for human capital development (World Bank 2018).

In conclusion, the utilitarian-driven leitmotif regarding the purpose of education was always central to the Bank's education discourse: education should serve the purpose of fostering the economic development of states and societies. However, the notions have changed from viewing education as instrumental for training technicians, to a strict neoliberal human capital approach in the 1980s, to the rather holistic and evidencebased understanding of education nowadays, which emphasizes the positive effects that high-quality education can have on both economic and social developments. The economic core of the Bank's education belief system became supplemented with other more holistic views on education. Alternative ideational concepts of education were acknowledged but eclipsed by the paramount significance of the economic view on education. While the World Bank's Education Strategy 2020 recognizes the limits of the market model for education development and ostensibly states that education is a human right (World Bank 2011), it still reflects an economic paradigm in education and basically promotes the global standardization of curricula, private-public education partnerships for designing and conducting education projects, and the decentralization of national education systems.

\section{The OECD: A Forum for Reconstruction Became a Trendsetter in Global Education}

A similar pattern to the World Bank can be identified when examining the education ideas of the OECD. Initially, the OECD was perceived as the "economic counterpart to NATO" in that it provided channels for its member states to consult and coordinate in order to achieve economic prosperity (Martens and Jakobi 2010,3). Like the World Bank, the 
OECD was created without a formal mandate in education. Over the course of its existence, however, the IO successively extended its thematic scope to issues of education. I show that the OECD framed education as a fundamental precondition for prosperity in individuals as well as in national economies. While the OECD is also an IO with a background in economic policies, it does not have the same explicit developmental focus as the World Bank.

Today, the OECD is widely considered one of the most influential education IOs. This is surprising because the OECD lacks any legislative teeth (Istance 1996, 95) and never planned to be an IO that provided factual development assistance to its members. Instead, it had only planned to be one that provided a forum to enable policy cooperation and discourse among states (Wolfe 2008, 208). Being an IO that exclusively relies on soft governance techniques, the OECD became an influential "knowledge broker" in education (Niemann and Martens 2018) by disseminating its ideas on what a desired outcome of education is and how national education systems should be organized. The Programme for International Student Assessment (PISA), a standardized large-scale assessment of education outcomes, was the main carrier of the OECD's education ideas and served as a powerful influence on states' policymaking. Despite the prominence of PISA within the OECD's education branch, the IO also covers topics that go beyond primary or secondary education and focuses extensively on issues related to higher education or vocational training (Seitzer et al. 2021). Although an IO with restricted membership rules, the OECD claims global validity through PISA that determines the best practices in education worldwide, and influences education reform processes that did not even participate in the PISA study (Niemann and Martens 2018). This process takes place by ideationally linking education improvements to economic advancements. The history of the OECD's activities in education sheds analytical light on the evolution of this view.

In its early years (1948-1960), ${ }^{4}$ when the topic of education was not directly on the IO's agenda, the OECD's endeavors reflected the fundamental task of improving its member states' scientific and commercial

\footnotetext{
${ }^{4}$ At this time, the OECD was the Organisation for European Economic Co-operation (OEEC).
} 
performances in the face of pressing challenges at that time, for example, the reconstruction of Europe after WWII, a need for economic stabilization, and an increasingly tense confrontation with the Soviet Union (Woodward 2009; Tröhler 2014). The founding treaty of the OECD set the tone that "economic strength and prosperity are essential for ... the preservation of individual liberty and the increase of general well-being" (OECD 1960). Accordingly, the OECD's persistent mantra can be summarized as follows: if the economic situation improves, the social situation is assumed to also improve.

This view is also continuously reflected in the OECD's education work. At the beginning, from the early 1960s to the mid-1970s and at the height of the leading paradigm of Keynesianism, the OECD addressed education in the context of scientific advancement. Over time, the emphasis of the OECD's education perspective progressively shifted toward social equity objectives and became closely linked to issues related to the labor market (Papadopoulos 1996). In consonance with the core tenet of Keynesianism, the OECD advocated increased state intervention in multiple policy areas (Armingeon 2004). This principle was also applied to education due to the assumption that stronger state intervention and centralization was beneficial for the overall outcome. With the establishment of the Centre for Educational Research and Innovation (CERI) in 1968 and the Education Committee in 1970, education policy was more formally institutionalized within the OECD and underscored the relevancy of education topics for the IO (Martens and Wolf 2006). In this period, the education perspective of the OECD was slightly decoupled from the overarching agenda of economic growth, and education developed into a more emancipated, self-contained issue within the IO.

In the mid-1970s, the OECD again turned its attention to education as an essential generator of economic growth (Rubenson 2008). In this phase, the social and equity components of education policy "receded to the background, giving way to economic concerns" (Papadopoulos 2006, $25)$. Eventually, this topical turning point gave rise to a reinterpretation of education and the economic perspective returned. This perspective was considerably strengthened in the 1980s, when the OECD's education initiatives were increasingly fueled by neoliberal interpretations. The 
OECD focused on "how to adjust education to changing economic requirements in the context of stagnating budgets" (Mundy 2007, 28) and moved to a neoclassical supply-side orientation (Sellar and Lingard 2014). Eventually, social and equity concerns were dominated by utility considerations.

Similar to other IOs (e.g. the ILO-see below), the end of the Cold War was a decisive watershed for the OECD. At the dawn of a new era, the IO looked somewhat anachronistic in its traditional role as a defender of Western values versus a competing bloc (Woodward 2008, 33). The OECD needed to redefine its own mission. Ultimately, this also had a substantial effect on the IO's activities in education. By referring to upcoming challenges due to globalization processes, the OECD increasingly emphasized the development of human resources to counteract emerging negative effects (OECD 1996; Henry et al. 2001). The idea of preparing education systems for future challenges has become a foundational part of the OECD's stance on education. Education was defined as a driving force for growth and development, and the OECD was committed to improving the quality of its member countries' education systems (OECD 2010-2011). The OECD proactively worked on strategies that dealt with the role of education in times of intensified globalization and in light of the emerging knowledge society. It did so by conducting reviews, producing empirical comparative data, and scrutinizing its member countries' education systems. Therefore, the surveys of the OECD progressively took the economic implications of social policies into consideration (Armingeon 2004, 226). The empirical data was supposed to enable policy actors to draw inferences from the returns of human capital produced through education. For instance, a strong positive correlation between economic effects and educational background was pointed out (OECD 2009, 5).

Together with the intensified research, a focus on the institutionalization of education took place. Most prominently, PISA was established. In 1997, the PISA resolution was adopted, and beginning in the year 2000, the standardized PISA study has been conducted every three years and has substantially contributed to the OECD's status as a leading IO in the field of education-particularly since the IO started to interpret PISA findings by itself in 2006. Furthermore, after the establishment of the 
Directorate for Education in 2002 and the Global Forum on Education in 2005, it became clear that the OECD's work on education occupied a distinctive niche within the IO. The established bureaucratic structures enabled the OECD to become an increasingly independent producer and disseminator of knowledge in the education field (Morgan and Shahjahan 2014, 198).

In terms of the ideas of the OECD, the advancement of education systems should contribute first and foremost to human capital formation and secondarily to the progress of social citizenship (Robertson 2005, 157). The OECD views human capital as "a major driver of a country's trend productivity, not least through its impact on innovation" (OECD 2010c, 18). The economic-focused education policy framework was settled mostly in the 1990s, when the aspect of equity was detached from issues of redistribution; instead, it was linked to the aspect of human capital in a globalized world. Education was increasingly heralded as "the policy key to the future prosperity of nations" (Henry et al. 2001, 30). Particularly from the OECD's perspective, education is a resource for innovation and to manage economic challenges. At this point, the theory of human capital is used to comprehend the OECD's policy framework in education (OECD 1996, 1998).

However, the predominance of economic interests within the OECD's education approach has always been put into perspective by the inclusion of the social dimension - though the social dimension has been subordinated to economic considerations. For instance, the OECD noted that education serves the provision of social cohesion and overall well-being, including health issues (OECD 2010b). Remarkably, social cohesion refers to economic factors; in order to create more social cohesion, education should enable individuals to advance economically. National education systems "need to equip people with knowledge, skills and tools to stay competitive and engaged" (OECD 2010-2011,3). The findings of the OECD's infamous PISA analysis confirm the positive returns on employment, earnings, well-being, and contributions to society for the individual as well as for the economy at large (OECD 2010a, 58). Education was meant to provide support for the economy, as the economy is responsible for securing and fostering the well-being of the whole society. Concerning this matter, social dimensions were also included in 
the OECD's leitmotif of education-however, under an economiccentered framework. The OECD deviated further from the strict economic notion of the education purpose with its 2030 learning compass, where societal well-being was defined as a key role of education. ${ }^{5}$

Taken together, the education leitmotif of the OECD was twofold. On the one hand, individuals benefit from education since they are enabled to increase their quality of life with better employment and higher economic returns. On the other (macroeconomic) hand, states also substantially benefit from education by fostering economic growth and strengthening social cohesion and the welfare state. Alternatively, the economic-centered purpose of education posed by the OECD was reduced to the point where the only real objectives were for students to gain better job opportunities for individual well-being and to the calculus of states to gain maximal returns on minimum inputs.

\section{UNESCO: A Specialized Education IO in Need of Respecialization}

Unlike the World Bank or the OECD, education has a lifelong and central relevancy for UNESCO. This is no surprise given that the specialized agency of the UN was explicitly established to deal with education, science, and culture. And unlike the IOs with an economic-oriented background that tend to focus on the utilitarian value of education in terms of economic outcomes, UNESCO has a different ideational take on the purpose of education. UNESCO, like the ILO, always emphasized the positive effect of education on individual well-being and social integration processes. The foundation for this understanding can already be identified in UNESCO's original mission, which was an instrumental approach to secure peace through education and to declare access to education as a universal human right. In addition, the IO's central concern in education policy has always been about the right to education and to ensure that this right is respected and delivered (Interview UNESCO C 2019).

\footnotetext{
${ }^{5}$ https://www.oecd.org/education/2030-project/teaching-and-learning/learning/learningcompass-2030/in_brief_Learning_Compass.pdf, last accessed 10/22/2020.
} 
Regarding its modus operandi, UNESCO was always a programmatic IO that set normative stimuli and cooperated with global, regional, and local stakeholders as opposed to an IO with an all-encompassing field presence (Lerch and Buckner 2018, 32-33). UNESCO also generates its own data on education, especially through its Institute for Statistics, where it draws on this data when making decisions regarding its program. However, the norms and values that the IO has incorporated are considered more important for UNESCO's policy program (Interview UNESCO A 2019). UNESCO's general conference is held biannually, and more than 190 member states decide upon new priorities for the IO's program. Unlike the World Bank or UNICEF, each state has the same voting power, which makes it more egalitarian, on the one hand, but also more vulnerable to vetoes and prolonged decision-making, on the other hand. Hence, UNESCO is regarded as a highly politicized organization (Interview UNESCO B 2019) that is closely tied to the demands of its member states and less autonomous than, for example, the OECD. The biggest challenge for UNESCO was (and still is) the discrepancy between its wide objectives in education and its tight budget (Mundy 1999; Menashy and Manion 2016).

UNESCO's history of how it frames education has been comparatively stable; however, it has not been immune to global trends and general developments. Its purpose of education shifted over time to some degree, and new views were incorporated into UNESCO's ideational portfolio. First of all, the utilitarian view on education became strengthened. Additionally, the view that education was a means to gain economic benefits grew within the IO. Also, in response to the initiatives of economic IOs and their positive reception by national education stakeholders, UNESCO incorporated ideas like human capital generation and the applicability of acquired skills into its education leitmotif. Yet, above all, the principle that education is a human right that enables societal integration and peace is the most important. The historical developments of UNESCO illustrate this point.

After its inception in 1945, the IO's main goal and efforts in education were to eradicate illiteracy, especially among adults (Jones 2007). This means that the education purpose focused on the individual and the ability to live a self-determined and prosperous life. Following the adoption 
of the Universal Declaration of Human Rights by the UN General Assembly in 1948, UNESCO supported free and compulsory basic education (Jones 2007, 523).

Because internal and external challenges became more diverse in the developed and developing world due to economic and technical progress in the 1970s, UNESCO attempted "to construct a single, universal vision of global educational futures" by calling for alternatives to formal schooling in its "Learning to Be" report (Mundy 1999, 37). Throughout the early period of the Cold War, UNESCO aimed at socializing children and adults to have greater international awareness by teaching global values like human rights and diversity (Lerch and Buckner 2018, 29). The central mission of UNESCO's educational approach was still to secure peace.

From the mid-1970s, however, UNESCO was also affected by the gradual replacement of the Keynesian economic paradigm with neoliberal views, and the significance of UNESCO began to decline. More and more (notably Western) states began to align their welfare state policies with neoliberal ideas. Social investments in education were no longer considered primary policy tools.

In the late 1970 s and early 1980 s, the IO faced a major crisis. At the height of the Cold War, UNESCO was massively criticized, mostly from Western countries and particularly from the United States, for being a politicized and mismanaged IO. This was in part because UNESCO had increasingly aligned itself with various social movements led by states from the Global South that called for a profound restructuring of the world economic order in favor of developing countries and was thus challenging Western interests (Menashy and Manion 2016, 322). Tensions rose and ultimately led to the withdrawal of the United States, the United Kingdom, and Singapore in 1984-1985. For UNESCO, this not only meant a significant drop in its budget by around a third but also a significant loss of legitimacy. As Jones put it: "the designated 'lead agency' in the UN system for education, UNESCO ... was incapable of exercising leadership in any of its multiple areas of responsibility" (Jones 2007, 
527). ${ }^{6}$ Due to this crisis, Mundy argues that UNESCO's work in education did not provide the IO with the necessary legitimacy and authority; furthermore, between 1984 and 1988, no major impulses were added to its education activity portfolio (Mundy 1999, 39, 42).

Another aspect of UNESCO's decline was the rising importance of other IOs in the education field. With UNESCO's legitimacy fading and the quality of its education work declining since the 1970s, IOs like the World Bank, the OECD, and UNICEF stepped in (Burnett 2011). This resembled a shift from cooperation to competition, as previously UNESCO had relied on operational funding from the World Bank and UNICEF (among others) to conduct on-site projects and UNESCO's expertise in education had been welcomed by other IOs (Jones 2007, 528). Starting in the 1980 s, both funding agencies began to develop their own expertise in education and established their own specialized education initiatives.

After troublesome years, UNESCO's leading role in education resurfaced with the 1990 World Conference on Education for All, where UNESCO made a strong case for universal basic education. UNESCO was able to "re-enter a more public dialogue with its multilateral partners ... and... rebuild its role as a mediator between developing country 'needs' and the resources available from donor governments" (Mundy 1999, 44). With the World Education Forum in 2000, where UNESCO once again was the lead agency, the general position was reconfirmed that education is not only a fundamental human right but also "an essential ingredient in the promotion of a global culture of peace, sustainable development, equity, and social cohesion" (Menashy and Manion 2016, 323). With both initiatives, UNESCO synthesized cooperation with the World Bank and other IOs.

In the context of the SDGs of 2016, UNESCO reemphasized its view that educational development should contribute to social justice and equality (Vaccari and Gardinier 2019, 72). "These times are calling for a new humanism that marries human development with the preservation

\footnotetext{
${ }^{6}$ Although the United States rejoined UNESCO in 2003 (UK in 1997 and Singapore in 2007), the relationship remained rocky. In 2011, the United States suspended its payments again in response to the acceptance of Palestine as a member and, together with Israel, left UNESCO for the second time in 2018.
} 
of the planet and that provides equal access to all to the benefits of education" (UNESCO 2014, 7). The SDGs, particularly SDG4 that explicitly deals with education, also set new priorities and strongly influenced UNESCO's work in the field of education. The general approach of the SDGs as a whole introduced to UNESCO a more holistic view on education and linked the topic of education to other issue areas, first and foremost to climate change (Interviews UNESCO A and C 2019).

UNESCO's ideational view on the purpose of education became more consistent over time. Throughout its existence, UNESCO was successful in providing a normative framework that saw the various dimensions of human rights as interdependent and indivisible (Jones 2007, 528). The initial focus of UNESCO included peace as an overall outcome for education, but later the IO linked education and conflict with an additional interpretation of peace as a necessary precondition for individuals' educational success (Lerch and Buckner 2018). UNESCO emphasized that education strengthens "the foundations for international understanding, co-operation and peace and the protection of human rights" (UNESCO $1991,4)$. Hence, the focus in the context of education and conflict shifted from a collective interpretation to a more individualistic one. This was also reflected in other areas of the IO's education leitmotif. UNESCO strongly emphasizes the social value of education for integration but also for individual economic development.

Basically, scientific humanism was the leading idea of UNESCO since its establishment and shaped how education was framed; education was understood as a lifelong process where the social dimension of cultural (re-)production was included (Menashy and Manion 2016, 322). The IO therefore focuses on a humanistic and holistic understanding of education, where the self-development and the well-being of individuals and society are dominant rather than the development of skills for the labor market (Interview UNESCO A 2019). In its 2014 mission statement, UNESCO reemphasized that education "contributes to the building of peace, the eradication of poverty, and sustainable development and intercultural dialogue through education, the sciences, culture, communication and information" (UNESCO 2014, 13). UNESCO stresses that universal norms and duties help individuals to become members of society, as they transport values, history, and traditions to ensure social and 
cultural cohesion (UNESCO 1996, 9, Interviews UNESCO A, B 2019). Hence, social cohesion and social justice play an important role when it comes to specifying the purpose of education for UNESCO.

While other IOs, especially the OECD, frame education in the line of competencies, UNESCO connects citizenship values of education to the individual, viewing them as rights-holders. For UNESCO, the acquisition of skills was strongly associated with enacting social change and equality (Vaccari and Gardinier 2019, 78, 79). Education is not only the transmission of knowledge but also an avenue to self-empower people. Generally, it should be ensured that education programs prepare people to become responsible members of a global society and empower them to become active citizens (Interview UNESCO A 2019). Hence, for UNESCO, there are not only economic returns from an investment in education but there are also societal returns (Interview UNESCO C 2019). And regarding the SDGs, UNESCO put forward the strategic objective that "[e]ducation, learning and skills are both enablers and drivers of inclusive and sustainable development and it is widely acknowledged that no country can improve the living conditions of its people without significant investment in education" (UNESCO 2014, 17). However, UNESCO also stressed that making education more inclusive for different (marginalized) social groups contributes to fighting poverty and to the broader goals of social justice and social inclusion (UNESCO 2008).

\section{The ILO: Linking Decent Work and Decent Education}

The ILO is an IO that is primarily concerned with employees' rights and other job-related issues, but it is always addressing education topics too. Because of the ILO's focus area, education has been associated with vocational training and individual skill formation. Education policy initiatives of the ILO were usually coupled with topics of training and development, particularly for countries in the Global South.

Generally, the ILO is a norm-setting organization in education that reflects a soft governance approach without having the ability to enforce decisions. While ratified recommendations are a powerful and binding 
tool, most of the ILO's work in education comprises analyses as well as on-site studies, regional monitoring, and nonbinding best practice advice. In the field of education, the ILO has a long history of cooperating with other actors that hold the same ideational mindset. For example, UNESCO and the ILO have been strategic partners in the field of education for a long time. As early as 1948, both IOs agreed to collaborate on technical and vocational education (Mundy 1999, 31).

The ILO's primary mandate is to protect working people, to promote labor and human rights, and to promote social justice (Hughes 2005, 413). Like UNESCO, the ILO emphasized a holistic and humanistic leitmotif in education and did not bring utilitarian economic views to the fore. Although the economic dimension of education issues was always existent in the ideational portfolio of the ILO, it never overshadowed the social citizenship interpretation. In contrast to the World Bank and the OECD, the ILO's understanding of economic education ideas was to focus on the benefits for the individual and not on the whole economic development of states.

The ILO's humanistic, social take on the purpose of education is also reflected in the IO's history and its view on education over time. Since its inception in 1919, the ILO was concerned with broader social welfare policies (Strang and Chang 1993) and highlighted the social significance of education for the improvement of quality of life (Steffek and Holthaus 2018). In its Declaration of Philadelphia from 1944, the ILO defined one of its tasks as being to support "the assurance of equality of educational and vocational opportunity" (ILO 1944).

Since the 1950s and 1960s, technical assistance programs of the ILO in cooperation with domestic stakeholders became more important, particularly in developing states in Asia and Africa. Consequently, the ILO engaged in educational program activities (Strang and Chang 1993, 241; Interview ILO A 2019). Successively, the ILO expanded its initiatives on labor protection to also cover "the domain of human rights and tie these to the pursuit of freedom and economic progress" (Hughes 2005, 414). This gradual shift also has some important implications for the ILO's work in education and training because with this altered emphasis, matters of education were pulled into the ILO's sphere of responsibility. As the ILO stresses the importance of equal opportunities as a basic human 
right, it necessarily implies the relevancy of it for education as well. Equal opportunities can best be achieved by ensuring access to high-quality education for all children and adults in the view of lifelong learning. Here, the holistic and humanistic leitmotif of the ILO in education was evident: "Education ... should be directed to the all-round development of the human personality and to the spiritual, moral, social, cultural and economic progress of the community, as well as to the inculcation of deep respect for human rights and fundamental freedoms" (UNESCO and ILO 1966, 4).

While the ILO remained a central education actor with its technical reports and approaches to support development in the 1970s and 1980s, the upcoming neoliberal zeitgeist made it difficult for the IO to maintain its significance in the international system (Haworth and Hughes 2012, 205). A new framework approach was required that would also influence the ILO's work in education. After the end of the Cold War, the ILO started to address how market liberalism and intensified globalization processes affected social rights and sought to integrate universal labor standards into international trade agreements.

Eventually, with the 1998 Declaration on Fundamental Principles and Rights at Work and its Follow-Ups, the ILO postulated "Core Labour Standards" (CLS) and expanded beyond issues directly related to work. The ILO directly referred to basic human rights and societal values that needed to be enhanced (Hughes 2005). The CLS "were framed as truly global, a set of rights which does not need national government approval" (Römer et al. 2021). Due to this framework, the right to education was emphasized by the ILO and the function of education as a means for individual self-development was stressed. Hence, the topic of education was decoupled from the direct linkage to the work environment, where it became a more independent topic area of the ILO.

More importantly, the ILO's Decent Work Initiative of 1999 affirmed the understanding that social norms and values must be reinforced; workers should be enabled to benefit from economic growth due to the necessary skills and opportunities education provides (Hughes 2005). Among other things, the ILO stipulated that education systems should be designed to enable knowledge transfer and skill formation, especially for disadvantaged socioeconomic groups. The ILO later argued that 
education is a central pillar for "employability, employment of workers and sustainable enterprise development within the Decent Work Agenda" (ILO 2008, 1). While the overall focus was still on vocational training, the general education idea of the ILO became apparent in the Decent Work Initiative: education enables people to "achieve full personal development and social inclusion through work participation" (Deranty and MacMillan 2012, 391). Hence, by focusing on the individual, the purpose of education goes beyond enhancing economic productivity. Due to the realization that workers need decent work, education became a primary objective of the ILO and the IO came to recognize "that education, training and lifelong learning are contributing factors to personal development, access to culture and active citizenship" (ILO 2004, 1).

The key education ideas of the ILO are reflected in the fact that the IO generally follows a human rights approach and denotes the importance of universally valid norms. Against the background of the ILO not seeing labor as a commodity, the term human capital is critically evaluated and not regarded as central to the ILO's own view (Interviews ILO A, B 2019). Instead, enhancing human capabilities was put to the forefront of the ILO's understanding of education (Interviews ILO B, C 2019). In this context, the perspective on the individual becomes apparent in the ILO's education idea. Central to the IO is the view that education should qualify individuals for the labor market by activating skills (Interviews ILO A, B, C 2019). This skill building is not solely focused on technical skills but also understood as acquiring soft skills for professional transitions within the labor market. (Interview ILO C 2019). In this regard, the purpose of education for the ILO has a strong emphasis on enabling individuals to cope with job-related challenges but also on the promotion of lifelong learning. However, for the ILO, the goal of education is more than just labor market preparation; it also prepares people for community life and related social tasks (Interview ILO A 2019).

Another dimension of the ILO's educational work is reflected in the context of the supply-side of education systems: teachers. A large share of the ILO's activities in education has always dealt with the improvement of the work environment and employment conditions for teachers. On the one hand, teachers are employees whose interests should be represented by the ILO. On the other hand, the ILO also acknowledges that 
improving the job conditions of teachers and higher education personnel has important consequences for the education system as a whole (Interview ILO A 2019). If teachers are better trained, the general quality of education improves.

It is important to note that the perspective on the economic benefits of education is not neglected by the ILO. Improvements in education systems could lead to economic growth, but the ILO stresses that education developments in the economic sector and the labor market must be viewed in tandem: "Skills are fundamental to, but not sufficient for, gaining decent jobs: linking skills with employment opportunities and decent work is critical" (ILO 2012, 2). If the focus is solely on providing better access to higher education but the national job market is not readily developed for a highly skilled labor force, the general economic improvement is nullified.

In connection with individual skill formation, an education purpose that promotes social cohesion, social justice, and integration is also deemed important to the ILO (Interviews ILO A, C 2019). Recent developments in the ILO's education concepts indicate that the purpose of education should extend beyond the labor market and increasingly aim at promoting active citizenship. ${ }^{7}$ Even more, the ILO has established the flagship program "Jobs for Peace and Resilience", where skill formation is conceptualized as the cornerstone of the strategy (Interview ILO B 2019).

These examples underscore that the ILO's leitmotif regarding the purpose of education became more diverse over time. The strict link to jobs and the labor market was weakened, while a perspective that acknowledges a broader purpose of education was institutionalized. Against the background of accelerating globalization processes, which bring about new challenges for employability and skill formation, the ILO emphasized the interconnectedness of different relevant aspects of education: skill formation, equal opportunities, economic development, and social cohesion. However, the view of the ILO in education still prioritizes the perspective of individual workers. Therefore, improvements in education are expected to improve the situation of individuals.

\footnotetext{
${ }^{7}$ See: Future of Work reports and position papers: https:/www.ilo.org/global/topics/future-ofwork/lang\%2D\%2Den/index.htm, last accessed 10/22/2020.
} 


\section{Conclusion and Discussion: A Reflection on Integrative Ideas}

When comparing the ideational framings of the education purposes of the four IOs, we can identify several differences but also some shared views that existed early on. All IOs consider education and access to education as a basic human right. While UNESCO and the World Bank stated it first, the OECD and the ILO also emphasize the importance of education as a fundamental right of each individual. At the beginning of their educational activities, the two economic IOs (the World Bank and the OECD) were strongly associated with economic interpretations of education topics, reflecting their original field of expertise. Later, they broadened their ideational portfolio in education and also embraced views that did not necessarily focus on maximizing productivity and human capital. Instead, interpretations of the education purpose related to individual well-being and social cohesion came to the center of their leitmotifs. In addition, the IOs with humanistic education ideas (the ILO and UNESCO) expanded their ideational views on education by acknowledging the role of education in fostering national economic growth.

However, it has been shown above that the four globally operating education IOs prioritized different ideas on education. Basically, a dualism between economic utilitarian views (World Bank and OECD) and idealistic humanistic (UNESCO and ILO) views can be identified. This dualism was embodied in the IO's education programs from the beginning and was translated into concrete actions and policy recommendations. An initial ideological rivalry between the "old dogs" (UNESCO and the ILO) and the "new kids on the block" (the World Bank and the OECD) can be observed. Since the latecomer education IOs from the economic sphere (the World Bank and the OECD) had more resources readily available and were backed by national governments, the wellestablished IOs (UNESCO and the ILO) saw them as competitors. Contestation between both types of IOs was also amplified by fundamentally different leitmotifs regarding the purpose of education. The globally dominant view on the purpose of education oscillated over time 
between the utilitarian and the humanistic citizenship perspective; depending on the leading economic paradigms and international developments of the time, the view on education accordingly shifted from one pole to the other, with education IOs being associated with one or the other.

While during some periods, like in the 1980s, the ideas were presented as mutually exclusive and contestation prevailed between the IOs, nowadays an integrative approach toward education ideas can be observed within the population of global IOs. By the end of the 1990s, this competition of ideas became less distinctive and dominant. This easing polarity could also be attributed to the IOs' activities and their ideational interpretation of education. In the two decades after the turn of the millennium, the IOs pursued an integrative approach in defining what the aim of education should be based on, which included empirical assessments that were less biased by ideational assumptions. While still viewing education either primarily as an economic endeavor or as a social right of citizens, the four education IOs analyzed in this chapter nonetheless acknowledged the opposing position and tied it into their own ideational leitmotifs. For example, in its 2018 World Development Report, the World Bank emphasized the integrative power of education, stating that national education systems should aim to educate students so that they become more refined human beings within society (World Bank 2018). On the other hand, UNESCO acknowledged in 2014 that one of the most important things education could accomplish includes skill development for the job market, so that individuals can contribute to the economic development of their country or society (UNESCO 2014). In contrast, the previous ideas remain valid. In 2018, UNESCO and the ILO stated in a declaration that "education is not a commodity" (ILO and UNESCO 2018). This underscores the prevalent framing of education as a human right. Hence, when analyzing the education ideas of individual IOs, the trend of general convergence must be revised. Also, the examples of the World Bank and the OECD show that some decoupling and showcasing took place. While both IOs ostensibly referred to holistic education ideas, including aspects of social cohesion, a utilitarian framing is predominant in their ideational portfolio when 
communicating their position on education. The economic utility of education outcomes is superordinate to all else.

While this chapter offered a comparative analysis of the changing priorities in the education leitmotifs of four global IOs, it certainly falls short in assessing the actual impact of the changing discourse. It was not in the scope of this chapter to link altered ideational framings to concrete policy actions taken by individual IOs. In this regard, the potential decoupling between ideas and on-site activities of IOs, which was coined by Weaver (2008) as "organized hypocrisy", was excluded from this analysis. Fontdevila and Verger (2020) have demonstrated that there is some discrepancy between the World Bank's "talk" and its "actions" when it comes to supporting the implementation of education programs.

\section{References}

Armingeon, Klaus. 2004. OECD and National Welfare State Development. In The OECD and European Welfare States, ed. Klaus Armingeon and Michelle Beyeler, 226-241. Cheltenham: Edward Elgar.

Barnett, Michael N., and Martha Finnemore. 2004. Rules for the World. International Organizations in Global Politics. Ithaca and London: Cornell University Press.

Béland, Daniel, and Robert H. Cox. 2011. Introduction: Ideas and politics. In Ideas and Politics in Social Science Research, ed. Daniel Béland and Robert H. Cox, 3-20. Oxford: Oxford University Press.

Blyth, Mark M. 2003. Structures Do Not Come with an Instruction Sheet: Interests, Ideas, and Progress in Political Science. Perspectives on Politics 1 (4): 695-706.

Bonal, Xavier, and Aina Tarabini-Castellani. 2009. Global Solutions for Global Poverty?: The World Bank Education Policy and the Anti-Poverty Agenda. In Re-reading Education Policies, ed. Maarten Simons, Mark Olssen, and Michael A. Peters, 96-111. Rotterdam et al.: Sense Publishers.

Burnett, Nicholas. 2011. UNESCO Education: Political or Technical?

Reflections on Recent Personal Experience. International Journal of Educational Development 3 (31): 315-318. 
Deranty, Jean-Philippe, and Craig MacMillan. 2012. The ILO’s Decent Work Initiative: Suggestions for an Extension of the Notion of 'Decent Work'. Journal of Social Philosophy 43 (4): 386-405.

Enns, Charis. 2015. Knowledges in Competition: Knowledge Discourse at the World Bank During the Knowledge for Development Era. Global Social Policy 15 (1): 61-80.

Fontdevila, Clara, and Antoni Verger. 2020. Walking the Washington Talk? An Analysis of the World Bank's Policy-practice Disjuncture in Education. In Shaping Policy Agendas, ed. David Dolowitz, Magdaléna Hadjiisky, and Romuald Normand, 162-183. Cheltenham: Edward Elgar Publishing.

Goldstein, Judith, and Robert O. Keohane. 1993. Ideas and Foreign Policy: An Analytical Framework. In Ideas and Foreign Policy: Beliefs, Institutions, and Political Change, ed. Judith Goldstein and Robert O. Keohane, 3-30. Ithaca and London: Cornell University Press.

Hasenclever, Andreas, and Peter Mayer. 2007. Einleitung: Macht und Ohnmacht internationaler Institutionen. In Macht und Ohnmacht internationaler Institutionen. Festschrift für Volker Rittberger, ed. Andreas Hasenclever, KlausDieter Wolf, and Michael Zürn, 9-37. Frankfurt am Main: Campus.

Haworth, Nigel, and Steve Hughes. 2012. The International Labour Organization, Handbook of Institutional Approaches to International Business. Cheltenham: Edward Elgar.

Henry, Miriam, Bob Lingard, Fazal Rizvi, and Sandra Taylor, eds. 2001. The OECD, Globalisation and Education Policy. Oxford: IAU Press/ Pergamon.

Heyneman, Stephen P. 2003. The History and Problems in the Making of Education Policy at the World Bank 1960-2000. International Journal of Educational Development 23 (3): 315-337. https://doi.org/10.1016/ s0738-0593(02)00053-6.

Heyneman, Stephen P., and Bommi Lee. 2016. International Erganizations and the Future of Education Assistance. International Journal of Educational Development 48: 9-22.

Hughes, Steve. 2005. The International Labour Organisation. New Political Economy 10 (3): 413-425.

ILO. 1944. Declaration of Philadelphia. Geneva: International Labour Office. . 2004. R195-Human Resources Development Recommendation. Geneva: International Labour Office.

. 2008. Conclusions on Skills for Improved Productivity, Employment Growth and Development, International Labour Conference 2008. Geneva: International Labour Office. 
2012. Formulating a National Policy on Skills Development, Skills for Employment_Policy Brief. Geneva: International Labour Office.

ILO and UNESCO. 2018. Education is Not a Commodity: Teachers, the Right to Education and the Future of Work. https:/www.ilo.org/wcmsp5/groups/ public/\%2D\%2D-dgreports/\%2D\%2D-dcomm/\%2D\%2D-publ/documents/meetingdocument/wcms_646338.pdf. Last accessed 07/20/2021.

Istance, David. 1996. Education at the Chateau de la Muette. Oxford Review of Education 22 (1): 91-96. https://doi.org/10.1080/0305498960220106.

Jones, Phillip W. 2007. WCEFA: A Moment in the History of Multilateral Education. In Education For All: Global Promises, National Challenges, ed. David P. Baker and Alexander W. Wiseman, 521-538. Amsterdam: Elsevier. Lerch, Julia C., and Elizabeth Buckner. 2018. From Education for Peace to Education in Conflict: Changes in UNESCO Discourse, 1945-2015. Globalisation, Societies and Education 16 (1): 27-48.

Martens, Kerstin, and Anja P. Jakobi. 2010. Introduction. The OECD as an Actor in International Politics. In Mechanisms of OECD Governance. International Incentives for National Policy Making? ed. Kerstin Martens and Anja P. Jakobi, 1-30. Oxford: Oxford University Press.

Martens, Kerstin, and Dennis Niemann. 2013. When Do Numbers Count? The Differential Impact of Ratings and Rankings on National Education Policy in Germany and the US. German Politics 22 (3): 314-332.

Martens, Kerstin, and Klaus-Dieter Wolf. 2006. Paradoxien der Neuen Staatsräson. Die Internationalisierung der Bildungspolitik in der EU und der OECD. Zeitschrift für Internationale Beziehungen 13 (2): 145-176.

Martens, Kerstin, Alexander-Kenneth Nagel, Michael Windzio, and Ansgar Weyman, eds. 2010. Transformation of Education Policy. Basingstoke: Palgrave Macmillan.

Mayring, Philipp. 2003. Qualitative Inhaltsanalyse. Grundlagen und Techniken. Weinheim: Beltz.

Menashy, Francine, and Caroline Manion. 2016. "The Historical Evolution and Current Challenges of the United Nations and Global Education PolicyMaking." In The Handbook of Global Education Policy, ed. Karen Mundy, Andy Green, Bob Lingard and Antoni Verger, 319-334. Chichester, UK; Malden, MA: John Wiley \& Sons.

Meyer, John W., John Boli, George M. Thomas, and Francisco O. Ramirez. 1997. World Society and the Nation State. American Journal of Sociology 103 (1): 144-181. https://doi.org/10.1086/231174. 
Morgan, Clara, and Riyad A. Shahjahan. 2014. The Legitimation of OECD's Global Educational Governance: Examining PISA and AHELO Test Production. Comparative Education 50 (2): 192-205.

Mundy, Karen. 1999. Educational Multilateralism in a Changing World Order: UNESCO and the Limits of the Possible. International Journal of Educational Development 19 (1): 27-52.

- 2007. Educational Multilateralism-Origins and Indications for Global Governance. In New Arenas of Education Governance. The Impact of International Organizations and Markets on Educational Policy Making, ed. Kerstin Martens, Alessandra Rusconi, and Kathrin Leuze, 19-39. Basingstoke: Palgrave Macmillan.

- 2010. 'Education for All' and the Global Governors. In Who Governs the Globe? Cambridge Studies in International Relations, ed. Deborah D. Avant, Martha Finnemore, and Susan K. Sell, 333-355. Cambridge, MA: Cambridge University Press.

Mundy, Karen, and Antoni Verger. 2015. The World Bank and the Global Governance of Education in a Changing World Order. International Journal of Educational Development 40 (1): 9-18. https://doi.org/10.1016/j. ijedudev.2014.11.021.

Nagel, Alexander-Kenneth, Kerstin Martens, and Michael Windzio. 2010. Introduction-Education Policy in Transformation. In Transformation of Education Policy, ed. Kerstin Martens, Alexander-Kenneth Nagel, Michael Windzio, and Ansgar Weymann, 3-27. Basingstoke: Palgrave Macmillan.

Niemann, Dennis, and Kerstin Martens. 2018. Soft Governance by Hard Fact? The OECD as a Knowledge Broker in Education Policy. Global Social Policy 18 (3): 267-283. https://doi.org/10.1177/1468018118794076.

- 2021. Global Discourses, Regional Framings and Individual Showcasing: Analyzing the World of Education IOs. In International Organizations in Global Social Policy, ed. Kerstin Martens, Dennis Niemann, and Alexandra Kaasch, 163-186. Cham: Palgrave Macmillan.

Niemann, Dennis, David Krogmann, and Kerstin Martens. 2021, forthcoming. Between Economics and Education: How IOs Changed the View on Education. In International Impacts on Social Policy. Short Histories in a Global Perspective, ed. Frank Nullmeier, Delia González de Reufels and Herbert Obinger. Cham: Palgrave Macmillan.

OECD. 1960. Convention on the Organisation for Economic Co-operation and Development. Paris: OECD Publishing. 
1996. Measuring What People Know. Human Capital Accounting for the Knowledge Economy. Paris: OECD Publishing.

- 1998. Human Capital Investment. An International Comparison. Paris: OECD Publishing.

—. 2009. Bildung auf einen Blick 2009: OECD-Indikatoren. Zusammenfassung auf Deutsch. Paris: OECD Publishing. . 2010-2011. Work on Education. Paris: OECD Publishing. . 2010a. Education Today 2010. The OECD Perspective. Paris: OECD Publishing. . 2010b. Improving Health and Social Cohesion through Education. Paris: OECD Publishing.

- 2010c. Policy Brief. Economic Survey of Germany. Paris: OECD Publishing.

Papadopoulos, George. 1996. Die Entwicklung des Bildungswesens von 1960 bis 1990. Frankfurt am Main: Peter Lang.

- 2006. The OECD and the Evolution of National Policies for Education, 1960-1990: An Overview. In Supranational Regimes and National Education Policies_Encountering Challenge, ed. Johanna Kallo and Risto Rinne, 21-26. Turku: Finnish Educational Research Association.

Robertson, Susan L. 2005. Re-imagining and Rescripting the Future of Education: Global Knowledge Economy Discourses and the Challenge to Education Systems. Comparative Education 41 (2): 151-170. https://doi. org/10.1080/03050060500150922.

- 2012. The Strange Non-Death of Neoliberal Privatization in The World Bank's Education Strategy 2020. In The World Bank and Education: Critiques and Alternatives, ed. Steven J. Klees, Joel Samoff, and Nelly P. Stromquist, 189-206. Rotterdam: SensePublishers.

Römer, Friederike, Jakob Henninger, and Le Thuy Dung. 2021. International Organizations and Global Labor Standards. In International Organizations in Global Social Governance, ed. Kerstin Martens, Dennis Niemann, and Alexandra Kaasch, 57-81. Cham: Palgrave Macmillan.

Rubenson, Kjell. 2008. OECD Education Policies and World Hegemony. In The OECD and Transnational Governance, ed. Rianne Mahon and Stephen McBride, 242-259. Vancouver: UBC Press.

Seitzer, Helen, Dennis Niemann, and Kerstin Martens. 2021. PISA, Policies, and Pathologies: The OECD's Multi-Centric View on Education. Globalisation, Societies and Education 19 (1): 198-212. https://doi.org/1 0.1080/14767724.2021.1878017. 
Sellar, Sam, and Bob Lingard. 2014. The OECD and the Expansion of PISA: New Global Modes of Governance in Education. British Educational Research Journal 40 (6): 917-936.

Steffek, Jens, and Leonie Holthaus. 2018. The Social-Democratic Roots of Global Governance: Welfare Internationalism from the 19th Century to the United Nations. European Journal of International Relations 24 (1): 106-129. https://doi.org/10.1177/1354066117703176.

Strang, David, and Patricia Mei Yin Chang. 1993. The International Labor

Organization and the Welfare State: Institutional Effects on National Welfare Spending, 1960-80. International Organization 47 (2): 235-262.

Tröhler, Daniel. 2014. Change Management in the Governance of schooling: The Rise of Experts, Planners, and Statistics in the Early OECD. Teachers College Record 116 (9): 1-26.

UNESCO. 1991. General Conference, Twenty-Sixth Session. Paris: UNESCO.

- 1996. Educational Policy Debate 1995, Observations and Proposals. Paris: UNESCO.

- 2008. International Conference on Education, Forty-Eighth Session. Paris: UNESCO.

- 2014. UNESCO's Medium-Term Strategy for 2014-2021. Vol. 37 C/4. Paris: UNESCO.

UNESCO and ILO. 1966. Recommendation Concerning the Status of Teachers. Paris: UNESCO \& ILO.

Vaccari, Victoria, and Meg P. Gardinier. 2019. Toward One World or Many? A Comparative Analysis of OECD and UNESCO Global Education Policy Documents. International Journal of Development Education and Global Learning 11 (1): 68-86.

Vetterlein, Antje. 2012. Seeing like the World Bank on Poverty. New Political Economy 17 (1): 35-58.

Weaver, Catherine. 2008. Hypocrisy Trap: The World Bank and the Poverty of Reform. Princeton: Princeton University Press.

Wolfe, Robert. 2008. From Reconstructing Europe to Constructing Globalization: The OECD in Historical Perspective. In The OECD and Transnational Governance, ed. Rianne Mahon and Stephen McBride, 25-42. Vancouver: UBC Press.

Woodward, Richard. 2008. Towards Complex Multilateralism? Civil Society and the OECD. In The OECD and Transnational Governance, ed. Rianne Mahon and Stephen McBride, 77-95. Vancouver: UBC Press. 
- 2009. The Organisation for Economic Co-operation and Development $(O E C D)$. London: Routledge.

World Bank. 1974. Education Sector Working Paper. Washington, DC: World Bank.

- 1999. Education Sector Strategy. Washington, DC: World Bank.

- 2011. Learning for All Investing in People's Knowledge and Skills to

Promote Development. In World Bank Group Education Strategy 2020. Washington, DC: World Bank.

- 2018. Learning to Realize Education's Promise. World Development Report 2018. Washington, DC: World Bank.

Zapp, Mike. 2017. The World Bank and Education: Governing (through) knowledge. International Journal of Educational Development 53 (1): 1-11. https://doi.org/10.1016/j.ijedudev.2016.11.007.

Open Access This chapter is licensed under the terms of the Creative Commons Attribution 4.0 International License (http://creativecommons.org/licenses/ by/4.0/), which permits use, sharing, adaptation, distribution and reproduction in any medium or format, as long as you give appropriate credit to the original author(s) and the source, provide a link to the Creative Commons licence and indicate if changes were made.

The images or other third party material in this chapter are included in the chapter's Creative Commons licence, unless indicated otherwise in a credit line to the material. If material is not included in the chapter's Creative Commons licence and your intended use is not permitted by statutory regulation or exceeds the permitted use, you will need to obtain permission directly from the copyright holder.

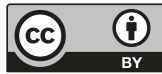

